\title{
Corruption and the Rule of Law in Sub-Saharan Africa
}

\author{
Stuart S. Yeh* \\ Associate Professor, University of Minnesota, Minneapolis, MN, USA
}

\begin{abstract}
The World Bank and IMF attribute underdevelopment in sub-Saharan Africa to the practice of directing economic activity through centralized planning. They prescribe privatization and economic liberalization to restructure African economies, promote competition, reduce the scope for corruption, and promote good governance. However, inadequate checks on political power permit African elites to subvert these reforms. This article reviews the political economy of sub-Saharan countries as well as a case study of Sierra Leone to illustrate the problem. The analysis suggests the need for an international agency such as the UN to provide the capacity to investigate, expose and check corruption by employing UN inspectors who are immune to pressure from powerful African elites. This type of check on corruption is necessary to promote the rule of law in sub-Saharan Africa.
\end{abstract}

\section{Keywords}

sub-Saharan Africa; corruption; development; economics; IMF; World Bank; political economy

\section{Introduction}

It is not controversial to assert that corruption is deeply engrained and undermines development in sub-Saharan Africa. What is debatable, however, is the most effective approach for addressing corruption. This article examines the views of the World Bank and the International Monetary Fund (IMF), as revealed in statements by senior World Bank and IMF economists. While the World Bank and IMF do not formally take a stance on the topic of corruption, a remarkably consistent stance may be inferred by explicit statements that have been made by senior officials and statements that are published on official World Bank and IMF websites. This stance emphasizes privatization and economic liberalization as the most effective means of reducing corruption.

If the World Bank and IMF had little influence on African countries, the views of their senior economists would primarily be of academic interest. However, these institutions have assumed a dominant - some would say hegemonic - role in dictating conditions that have produced wrenching economic and social

*) E-mail: yehxx008@umn.edu. 
changes in the vast majority of African nations. These conditions are tied to massive World Bank and IMF loans necessary to keep poverty-stricken nations from sliding even further into destitution and famine.

For these reasons, it is important to examine the assumptions upon which the views of senior World Bank and IMF economists are based. If the assumptions are incorrect, and if World Bank and IMF policies are based on incorrect assumptions, then there may exist an alternative set of policies that is more effective in addressing the underdevelopment that has characterized sub-Saharan Africa for the past 50 years.

At the core of this argument is the simple observation that all Western developed countries deter corruption through vigorous investigation and prosecution, rather than privatization and economic liberalization. Thus, it is apparent that investigation and prosecution must be central to any strategy for controlling corruption. However, while Western countries rely on domestic institutions to investigate and prosecute corruption, the concentration of unchecked political and economic power in African states neuters all domestic capacity to control corruption. Thus, there is a need for an international institution to assume this role. Since the United Nations (UN) is the only international institution with sufficient moral authority, resources, and the ability to field a large force of independent investigators who are resistant to pressure from powerful African elites, a logical conclusion is that the UN must create the capacity to conduct independent investigations.

This article is organized into four sections. Section 1 examines the views of the World Bank and the IMF, as revealed in statements by senior World Bank and IMF economists and statements published on official World Bank and IMF websites. Section 2 reviews the origin, nature and scope of corruption in Africa to suggest why domestic law enforcement institutions are completely overmatched by corruption in Africa, why the rule of law is weak, and why World Bank/IMF reliance on privatization and economic liberalization is misplaced. Section 3 illustrates the problem through a case study of Sierra Leone. Section 4 analyzes the problem and concludes that the monopoly on political and economic power that is exercised by African leaders fatally undermines domestic efforts to control corruption, requiring an international response involving vigorous investigations into allegations of corruption led by UN inspectors.

\section{The World Bank/IMF View}

Historically, the IMF and the World Bank have traced poor economic growth in sub-Saharan Africa to misguided dirigisme - the practice of directing economic activity through central planning - and have tied structural adjustment conditions to their loans in an attempt to restructure African economies in the mold of 
Western industrialized countries. ${ }^{1}$ This view is exemplified by a special World Bank publication devoted to the role of the state, as well as the view of Martin Wolf, former senior economist at the World Bank for 10 years:

\begin{abstract}
Most developing countries in Asia, the Middle East, and Africa came out of the colonial period with a strong belief in state-dominated economic development. The state would mobilize resources and people and direct them toward rapid growth and the eradication of social injustice. State control of the economy, following the example of the Soviet Union, was central to this strategy... By the 1960s states had become involved in virtually every aspect of the economy, administering prices and increasingly regulating labor, foreign exchange, and financial markets. By the 1970s the costs of this strategy were coming home to roost. ${ }^{2}$

Working as an economist (of the World Bank) on east Africa between 1972 and 1974 and then on India between 1974 and 1977, I learned first-hand of the damage done by dirigiste, inwardlooking economic policies. This was not only because of the grotesque inefficiency, but also because of the epidemic of corruption they caused. Throughout my ten years at the Bank, I was principally engaged in arguing for greater reliance on the market mechanism and trade. ${ }^{3}$
\end{abstract}

In contrast, prominent African economists identify the core problem as uncontrolled corruption - the abuse of governmental power for personal gain - rather than dirigisme, and explain that the preoccupation with dirigisme is itself misguided and leads to counterproductive policy prescriptions. ${ }^{4}$

The IMF and the World Bank acknowledge the existence of corruption but view it as an unintended consequence of earlier experiments with centralized economic planning.

The transition from socialism... [has been marked by administrative corruption and] has introduced scope in some nations for powerful interests to influence the structure of state institutions and the formulation and implementation of economic policy to their own advantage. This ingrained tendency toward state intervention... creates the potential for corruption. ${ }^{5}$

This paper views corruption largely as a symptom of weaknesses in economic structures and institutions, considered to be the origin of much of what is perceived as corruption in the public sector. Furthermore, the paper finds that once these weaknesses are defined and somehow 'measured,' they

1) The United Nations Conference on Trade and Development Secretariat, The Least Developed Countries 2000 Report: Aid, Private Capital Flows and External Debt: The Challenge of Financing Development in the LDCs (United Nations, New York 2000).

2) World Bank, World Development Report 1997: The State in a Changing World (Oxford University Press, New York 1997) p. 23.

3) M. Wolf, Why Globalization Works (Yale University Press, New Haven, CT 2005) p. xiii.

4) G.B.N. Ayittey, Africa Unchained: The Blueprint for Africa's Future (Palgrave MacMillan, New York, NY 2005); J.M. Mbaku, 'Bureaucratic and Political Corruption in Africa' in J.M. Mbaku (ed), Corruption and the Crisis of Institutional Reforms in Africa: African Studies Vol 47 (Edwin Mellon Press, Lewiston, NY 1998); J.M. Mbaku, 'Corruption and the Crisis of Institutional Reforms in Africa' in J.M. Mbaku (ed), Corruption and the Crisis of Institutional Reforms in Africa: African Studies Vol 47 (Edwin Mellon Press, Lewiston, NY 1998); J.M. Mbaku, 'Bureaucratic Corruption in Africa: The Futility of Cleanups' in J.M. Mbaku (ed), Corruption and the Crisis of Institutional Reforms in Africa: African Studies Vol 47 (Edwin Mellon Press, Lewiston, NY 1998).

5) World Bank, Anticorruption in Transition: A Contribution to the Policy Debate (The World Bank, Washington, DC 2000) p. 27. 
tend to provide a stronger link to economic performance than do measures of real or perceived corruption. Thus although corrupt behavior should always be addressed head-on by administrative means, the design of economic policies to deal with the phenomenon called 'corruption' is best pursued through structural and institutional reform. ${ }^{6}$

In this view, corruption will fade away with time as the role of government is reduced and the private sector and civil society strengthen:

A major thrust of any effective strategy to reinvigorate the public sector will be to reduce the opportunities for corruption by cutting back on discretionary authority. Policies that lower controls on foreign trade, remove entry barriers for private industry, and privatize state firms in a way that ensures competition - all of these will fight corruption. ${ }^{7}$

As of January 2011, the World Bank's own anticorruption website continues to emphasize anticorruption strategies based on economic policy liberalization and enhanced competition:

Deregulation of prices or other aspects of production or trade are important steps toward reducing opportunities for corruption. Implicit price subsidies, in the form of tax and utility arrears, provide politicians and bureaucrats with discretionary power that is highly subject to abuse... Enhancing competition, especially in concentrated sectors, by lowering barriers to entry, requiring competitive restructuring, and clarifying ownership structures are important elements toward creating a vibrant and corruption free private sector. ${ }^{8}$

In the World Bank's view, good governance and strong institutions are best developed through economic liberalization and competition, regulatory reform, improvements in transparency, instruments for increased voice, and transnational cooperation to fight corruption, because fundamental economic reforms remove the conditions that give rise to corruption in the first place and, therefore, are believed to be most effective over the long run:

The ability of powerful economic interests to capture the state can be constrained by: (i) economic policy liberalization; (ii) introducing greater competition, especially in concentrated sectors, by lowering barriers to entry, requiring competitive restructuring, and clarifying ownership structures; (iii) regulatory reform at all levels; (iv) a stronger and more transparent framework for corporate governance; (v) instruments of voice for business associations, trade unions, and concerned parties; and (vi) transnational cooperation. ${ }^{9}$

IMF policies are aligned with the policies of the World Bank and reflect the Word Bank's views. For example, senior IMF directors George Abed and Sanjeev Gupta

6) G.T. Abed and H.R. Davoodi, Corruption, Structural Reforms, and Economic Performance in the Transition Economies (The International Monetary Fund, Washington, DC 2000) p. 4.

7) World Bank, supra note 2 at 8 .

8) World Bank, 'Competitive Private Sector' <http://go.worldbank.org/DESSQB31N0> accessed 14 January 2011.

9) World Bank, supra note 5 at 48. 
examined the relationship between governance, corruption and economic growth. A section of their report, titled 'The Role of the IMF', states that the IMF's policy is to fight corruption by implementing economic liberalization and structural reforms (i.e., privatization of state assets):

The IMF is contributing to strengthening governance in member countries through various means. The first is by supporting economic policies and structural reforms that limit the scope for ad hoc decision making, for rent seeking, and for preferential treatment of individuals or organizations. This approach is founded on the IMF's mandate to promote macroeconomic stability, and limits its role to those aspects of governance that could have a significant macroeconomic impact... Increasing the reliance on market-based pricing and creating a sound regulatory environment should help in lowering corruption... The IMF's emphasis on deregulation, liberalization, privatization, and its techni$\mathrm{cal}$ assistance aimed at strengthening the budgetary process and institution building, help improve economic governance and reduce opportunities for rent-seeking behavior. ${ }^{10}$

Abed and IMF economist Hamid Davoodi assert that economic performance is fundamentally dependent on economic liberalization and privatization, rather than direct prosecution of corruption:

\begin{abstract}
It is the hypothesis of this paper that... economic performance... is related fundamentally to the achievement of these structural and institutional reforms and only incidentally to the degree to which corruption may have been reduced. Indeed, this paper claims that corruption per se (as measured by the widely used corruption perception indices) has much weaker explanatory power than variables measuring structural and institutional reforms. ${ }^{11}$
\end{abstract}

Thus, senior IMF and World Bank directors and economists favor privatization, structural adjustment, economic liberalization, and democratization as the most effective means to remove the distortions introduced by government, minimize opportunities for corruption, and maximize economic growth in countries previously characterized by dirigisme. ${ }^{12} \mathrm{~A}$ strong private sector is expected to demand governmental accountability and economic reform, and strengthened civil institutions are expected to institute checks and balances. ${ }^{13}$ These improvements in governance are, in turn, expected to lay the foundation for vibrant economic competition, an efficient business sector, and strong economic growth. Direct prosecution of corruption is viewed as helpful but tangential to the core problem of dirigisme.

10) G.T. Abed and S. Gupta, 'The Economics of Corruption: An Overview', online at: <http://www.imf .org/external/pubs/nft/2002/govern/> accessed 12 January 2010.

11) Abed and Davoodi, supra note 6 at $7-8$.

12) The United Nations Conference on Trade and Development Secretariat, supra note 1 at 102.

13) W. Reno, Corruption and State Politics in Sierra Leone (Cambridge University Press, Cambridge, UK 1995). 


\section{Origin and Nature of Corruption in Sub-Saharan Africa}

In contrast to the views of IMF and World Bank economists, Africa specialists suggest that corruption in Africa has its origin in colonial practices, has been deeply ingrained as a self-reinforcing, self-perpetuating institution, and has fundamentally captured governmental institutions in sub-Saharan countries in a way that insulates corrupt practices from ordinary reforms.$^{14}$ Colonial administrators dismantled traditional checks and balances to centralize power in their own hands and the hands of a small number of local chiefs, colonial appointees, and acculturated elites shaped by the colonial educational system. ${ }^{15}$ Local chiefs became accustomed to the exercise of absolute rule, without judicial restraint, as long as they enjoyed the confidence of the colonial administrator:

It is the chief who has the right to make a bylaw governing his locality, who assesses the value of your petty property and therefore how much tax you must pay, who comes to collect that tax, who fines you if you fail to pay that tax, who jails you if you fail to pay the tax and the fine, who decides where you labor when in jail, and who releases you upon termination of the sentence. The chief is the petty legislator, administrator, judge, and policeman all in one. Every moment of power - legislative, executive, judicial and administrative - is combined in this one official. ${ }^{16}$

This system invited abuses. A chief could requisition the third child of every subject as personal servants. Women were ruthlessly appropriated. Forced tribute was systematically extorted from the entire population under each chief's control, for personal enrichment. Thus, colonial practices institutionalized favoritism, aggrandizement and despotic rule, essentially training African elites in the methods of favoritism, the exercise of unbridled power, and personal enrichment. This legacy was to have disastrous results in the postcolonial period when the same elites replaced colonial administrators and re-applied well-learned lessons about the exercise of power. ${ }^{17}$

The central fact of postcolonial Africa is the tremendous concentration of economic and political power in each head of state. This concentration of power is a legacy of the French and British colonial practice of centralizing governmental power in the colonial head and his trusted elites. ${ }^{18}$ The transfer of this power to African heads of state had disastrous results upon independence. ${ }^{19}$ After the transfer of power, Africa's autocrats quickly discovered that they could use their

\footnotetext{
14) J.M. Mbaku, 'Corruption and the Crisis of Institutional Reforms in Africa,' supra note 4; Ayittey, supra note 4; M Mamdani, Citizen and Subject: Contemporary Africa and the Legacy of Late Colonialism (Princeton University Press, Princeton, NJ 1996).

15) Ayittey, supra note 4.

16) Mamdani, supra note 14 at 54 .

17) Ibid.

18) Mbaku, 'Corruption and the Crisis of Institutional Reforms in Africa,' supra note 4; Mbaku, 'Bureaucratic Corruption in Africa: The Futility of Cleanups,' supra note 4.

19) Mbaku, 'Corruption and the Crisis of Institutional Reforms in Africa,' supra note 4.
} 
combined economic and political power to direct economic activity, enrich themselves, reward political supporters, punish political rivals, and crush opposition to their rule. ${ }^{20}$ Political supporters were rewarded with government positions that permitted them to invent bureaucratic hurdles and then extract artificial license fees and fees to expedite requests through the bureaucracy, effectively throttling economic activity. ${ }^{21}$ The power to direct economic activity and to dispense government positions allowed African ruling elites to extract rents, build personal fortunes and dispense patronage to buy political support. ${ }^{22}$ The economic and political power invested in African heads of state was systematically abused for personal gain in one state after another, resulting in enormous personal fortunes.

Thus, Africa's dilemma is that 'The centralization of both economic and political power turns the state into a pot of gold that all sorts of groups compete to capture. Once captured, power is then used to amass huge personal fortunes, to enrich one's cronies and tribesmen, to crush one's rivals, and to perpetuate one's rule in office'. ${ }^{23}$ The ruling elite take over and subvert every key institution of government: the civil service, judiciary, military, media, and banking. ${ }^{24}$ Key positions in these institutions are handed over to the president's tribesmen, cronies, and loyal supporters. ${ }^{25}$ As a result, meritocracy, rule of law, property rights, transparency, and administrative capacity vanish. ${ }^{26}$ Suspicious of plots to overthrow them, strategic positions in the police and military are filled with personally loyal relatives and tribesmen. ${ }^{27}$ Economic reforms that would strip out state controls and eliminate scarcity are opposed because the controls are the source of the rents that are extracted by the ruling elites. Since political defeat could mean exile, jail, starvation, and the confiscation of all property and wealth, ruling elites refuse to relinquish or share political power. ${ }^{28}$ Those who are excluded from power resort to violence, insurgency and civil war. ${ }^{29}$

The preceding review suggests that the source of the problem of corruption in Africa is the colonial policy of dismantling traditional checks and balances on the power of rulers. Colonial governments used their power to extract wealth from their colonies, then transferred this power to African rulers upon independence,

20) Ibid.; Mbaku, 'Bureaucratic and Political Corruption in Africa,' supra note 4; GBN Ayittey, supra note 4 .

21) Ayittey, supra note 4; Mbaku, 'Bureaucratic Corruption in Africa: The Futility of Cleanups,' supra note 4

22) G.B.N. Ayittey, 'The African Development Conundrum' in B. Powell (ed), Making Poor Nations Rich: Entrepreneurship and the Process of Economic Development (Stanford University Press, Stanford, CA 2008).

23) Ayittey, supra note 4 at 48.

24) Mbaku, 'Bureaucratic and Political Corruption in Africa,' supra note 4; Ayittey, supra note 22.

25) Ayittey, supra note 22.

26) Mbaku, 'Bureaucratic and Political Corruption in Africa,' supra note 4; GBN Ayittey, supra note 22.

27) Ayittey, supra note 4.

28) Ayittey, supra note 22.

29) Mbaku, 'Corruption and the Crisis of Institutional Reforms in Africa,' supra note 4. 
where it was abused on a grand scale: 'With no effective restraints on government behavior, corruption became widespread'. ${ }^{30}$

The primary catalyst for corruption is a lack of accountability among the ruling elite, who use their monopoly on unchecked discretionary power for personal economic and political gain: 'It is through this stranglehold that corruption thrives, for it is through this stranglehold that all decision-making occurs and patronage is dispensed'. ${ }^{31}$ Corruption persists because 'public officials have no fear of being held accountable for their actions'. ${ }^{32}$ Despite public outrage, 'corruption in Africa has reached cancerous proportions. ${ }^{33}$ Elites have turned state institutions into instruments for self-enrichment; thus, 'corruption.... has become, in almost all African countries, a common and routine element of the functioning of the administrative and para-administrative apparatus, from top to bottom', leading to enormous losses in state revenue - in some cases as much as 60 per cent. ${ }^{34}$ Corruption in Africa is 'pandemic,' 'a way of life' and remains one of the continent's most enduring institutions. ${ }^{35}$ Corruption is not only caused by a lack of checks and balances but it also serves to prevent the emergence of the institutional reforms necessary to create checks and balances. In the majority of African countries, corruption pervades the institutions that normally provide checks and balances: the police, judiciary, and the legal system. Thus, it is not possible to rely on those institutions to fight corruption.

Elites sabotage the development of transparent, participatory, democratic accountability structures in order to preserve their lucrative monopolies on governmental services and privileges. Despite free elections, African leaders continue to resist IMF reforms that would undermine the patrimonial system that keeps them in power, and have delayed and reshaped reform policies in ways that make them less threatening and, in some cases, even profitable, as in the case where state assets are 'privatized' at fire sale prices to the president's cronies, with hefty fees going to government ministers. ${ }^{36}$ Thus, democratization, privatization and IMF-style reforms are not panaceas and do not provide checks and balances against the abuse of governmental power. Instead, 'the control of corruption... is a fundamental condition for the sustainable transition to a market-oriented economy $\cdot{ }^{37}$ Barro summarized the evidence and concluded that:

\footnotetext{
30) K.R. Hope, Sr., From Crisis to Renewal: Development Policy and Management in Africa (Brill, Leiden 2002) p. 102.

31) Ibid., 104.

32) Ibid., 109.

33) Ibid., 127.

34) J.-P. Olivier de Sardan, 'A Moral Economy of Corruption in Africa' (1999) 37 Journal of Modern African Studies: 28. W. Reno, Corruption and State Politics in Sierra Leone (Cambridge University Press, Cambridge, UK 1995).

35) Hope Sr., supra note 30 at 100.

36) N. van de Walle, African Economies and the Politics of Permanent Crisis, 1979-1999 (Cambridge University Press, Cambridge 2001).

37) Hope Sr., supra note 30 at 12.
} 
Even if a poor country could beat the odds and sustain democratic institutions, there is no reason to believe that this accomplishment would help much in the quest to escape poverty.... An increase in democracy is less important than an expansion of the rule of law as a stimulus for economic growth and investment. In addition, democracy does not seem to have a strong role in fostering the rule of law. Thus, one cannot argue that democracy is critical for growth because democracy is a prerequisite for the rule of law.... If a poor country has a limited amount of resources to accomplish institutional reforms, then they are much better spent in attempting to implement the rule of law... Even if democracy is the principal objective in the long run, the best way to accomplish it may be to encourage the rule of law in the short run. ${ }^{38}$

The persistence of Africa's problems despite democratization, privatization, and IMF reforms is puzzling except when viewed as the logical outcome of a lack of checks and balances. Recurring fiscal and balance of payments crises are predictable consequences of corruption, uncontrolled expenditures, and rent-seeking which drains revenue from government coffers, causing revenue to lag behind expenditures. A continued lack of transparency, accountability and honest, highly efficient civil servants may be understood as the logical outcome when ruling elites are permitted, through a lack of checks and balances, to use patronage networks to stay in power and, therefore, take every opportunity to subvert good governance. The continued pursuit of disastrous economic policies that would normally be disciplined by their consequences may be understood as the logical outcome when massive amounts of foreign aid provide the resources that allow African ruling elites to sustain those policies. Without checks and balances, aid is wasted and aid donors unwittingly undermine true reform, the development of strong institutions and the rule of law. ${ }^{39}$

The conclusion that corruption is the core problem underlying Africa's misery is hardly controversial. What is questionable is the assumption underlying IMF and World Bank policies toward sub-Saharan Africa, as revealed in the statements by senior IMF and World Bank officials in Section I, that corruption will fade away with time as the role of government is reduced and the private sector and civil society strengthen. The IMF and the World Bank seek to reduce the role of government and strengthen the private sector by attaching conditions to their loans that promote privatization of government assets, deregulation of prices, and increased competition in product and service markets.

The review of literature in Section II suggests that, in Africa, checks and balances against the abuse of governmental power are inadequate. As a consequence, privatization, elections, deregulation and the introduction of competition are frequently manipulated by those in power in ways that reward allies and punish rivals. The reforms that are required by the IMF and World Bank are often twisted in ways that undermine, rather than promote, the private sector and civil society,

\footnotetext{
38) R. Barro, 'Democracy and the Rule of Law' in B. Bueno de Mesquita and H.L. Root (eds), Governing for Prosperity (Yale University Press, New Haven 2000) p. 230.

39) Van de Walle, supra note 36.
} 
and undermine the fight against corruption and underdevelopment. Paradoxically, IMF and World Bank economists continue to advocate privatization, elections, deregulation, and the introduction of competition as the primary means of fighting corruption and promoting economic development in sub-Saharan Africa.

\section{The Case of Sierra Leone}

To illustrate how corrupt leaders subvert privatization, elections, deregulation, and competition to reward allies and punish rivals, I draw upon William Reno's detailed studies of Sierra Leone. ${ }^{40}$ These studies illustrate the dynamics of corruption and explain why the IMF's and World Bank's focus on privatization, economic liberalization, and competitive elections are likely to reinforce patrimonialism, exacerbate corruption, and undermine the goals of economic reform and growth. The interested reader will find similar studies for each of the major subSaharan countries..$^{41}$ In essence, the mechanisms whereby civil society and the mass of private citizens hold leaders accountable in Western democracies and ensure that privatization, economic liberalization and competitive elections promote good governance are broken in sub-Saharan countries such as Sierra Leone. The problem is not weakness that can be strengthened through economic and political liberalization, but the complete domination and manipulation of the rules of the game by those who are in power. This domination requires a different response than has previously been offered by the international community.

\subsection{The Political Economy of Indirect Rule}

Colonial rulers sought to maximize the profits that were extracted from their colonies by establishing systems of indirect rule, where colonial dictates were implemented by local chiefs who commanded the loyalty of their subjects, in order to minimize administrative payroll costs. However, the loyalty of the chiefs had to be purchased and enforced by colonial rulers. Over time, rewards and sanctions had to be increased in order to ensure loyalty. Any disloyalty or inefficiency would increase the time, effort, personnel, and cost required to implement the system of indirect rule. While the costs of the payoffs became substantial, they were outweighed by the profits obtained by colonial rulers. Furthermore, rulers could contain those costs by resorting to harsh sanctions. Thus, powerful incentives drove the development of a system of payoffs linked to despotic rule.

\footnotetext{
40) For the material in Section III, see Reno, supra note 34, and W. Reno, Warlord Politics and African States (Lynne Rienner Publishers, Boulder, CO 1998).

41) See, for example, M. Meredith, The State of Africa: A History of Fifty Years of Independence (The Free Press, London 2005).
} 
For the same reasons, local chiefs replicated this system of payoffs and despotic rule with regard to their subjects. Each chief sought to maximize his current and future stream of profits by selectively allocating privileges to individuals who displayed their loyalty by performing tasks that reinforced the chief's power. This included the use of force to enforce sanctions when subjects strayed. Essentially, the colonial practice of indirect rule institutionalized the use of payoffs and despotism in order to extract profits from the populace. African chiefs learned the required attitudes and skills at the feet of their masters, then applied the same attitudes and skills on a grand scale after independence.

\subsection{Controlling Diamond Profits}

The raison d'etre for establishing African colonies was to extract wealth from natural resources - diamonds, in the case of Sierra Leone. Typically, a colonial government awarded contracts to private firms that extracted, processed and sold the natural resources, then split the revenue with the government. Thus, in 1932, England awarded a 99-year monopoly on diamond mining to the Sierra Leone Selection Trust (SLST), a subsidiary of DeBeers, in exchange for a 27.5 per cent tax on net profits. However, revenues were threatened by illicit miners, whose sales were not taxed and, therefore, eroded the revenue base for the colony. Thus, the SLST monopoly was extended to the entire country and enforced by government laws designed to prevent the establishment of competing operations. Faced with declining state revenues, the Freetown government authorized SLST to field a force of thirty-five armed men to patrol the mining areas.

The SLST lease clashed with the customary rights of local chiefs, who accepted rents from 'illicit' tenant miners in exchange for protection. Believing that chiefs controlled the influx of illicit miners, SLST initiated informal payments of $£ 50$ to each chief who agreed to withhold settler rights, beginning a policy of payoffs that expanded over time. To ward off SLST patrols, illicit miners armed themselves with swords and machetes, while local chiefs parlayed their fortunes to finance personal armed forces. In response to these threats, the government implemented the Native Authority Scheme (NAS) of 1937. Local chiefs were enticed to become paid agents of the government through salaries aimed at replacing the 'customary' rents that chiefs traditionally received from illicit miners and merchants, with the goal of securing the loyalty and active cooperation of the chiefs in stamping out illicit mining. The Native Authority Scheme greatly increased the chiefs' legal incomes from about $£ 500$ per year in the 1930 s to enormous amounts (by West African standards) approaching $£ 10,000$ by the late 1940 s.

Even at this early stage, it is clear that neither the Freetown government nor the local chiefs desired economic or political competition. Economic and political competition from more actors would simply have exacerbated the problem of control that each actor faced. The government wished to control the country's 
diamond industry and maintain the associated stream of tax revenues by paying off the smallest number of chiefs possible, while local chiefs had no interest in splitting their power bases with any other actor. From the perspectives of the key actors, competition in either sphere would simply increase costs and/or reduce revenues and profits. This, in a nutshell, is the reason why IMF and World Bank reform policies are doomed to fail. Reforms designed to increase economic and political competition can only succeed if they benefit the actors who must enact them. If economic and political competition serves instead to undercut the livelihoods of these actors, there is every incentive for these actors to undermine the reforms by intensifying the corrupt arrangements that maximize their profits.

\subsection{Expansion of Corruption}

The Mining Area Development Administration (MADA) program, ostensibly to channel diamond mining revenues into local development, expanded corruption by channeling enormous $£ 10,000$ payments to compliant chiefs for maintaining social order as well as turning out Sierra Leone People's Party (SLPP) voters and harassing Kono Progressive Movement (KPM) supporters, who were critical of government restrictions on 'illicit' diamond mining. With the approval of District Commissioners, chiefdom treasuries increasingly turned state resources over to the chiefs' personal uses in order to buy their support for the colonial government and its policy of stamping out illicit mining. These expensive accommodations drained the treasuries of funds that could otherwise have been invested in development projects, causing Kono citizens to stop paying taxes. The government resorted to vigorous police and SLST security force attacks on illicit miners to collect revenue. The illicit diamond dealers and miners responded by organizing fifty-member youth gangs, structured like police riot units, to defend illicit mining operations. Dealers bought food and tools for the miners, paid rents to local chiefs, and gave the miners stakes in return for a share of revenues. Dealers supported the All Peoples Congress (APC) in exchange for APC-organized assaults and intimidation of chiefs attempting to stamp out illicit mining.

After independence, corruption and strong-arm tactics expanded into parliamentary politics, dominated by local chiefs and their descendents seeking to protect the political and economic privileges upon which they had built their power. For example, Paul Dunbar armed a fifty-man 'action group' to intimidate SLPP rivals and used his family ties to three Kono chieftain ruling houses to mobilize support for Dunbar's candidates for state and chiefdom offices. Once elected, these individuals defended Dunbar's political and economic privileges in Kono.

After consolidating power in 1968, President Siaka Stevens transformed SLST into a new state-owned mining company, the National Diamond Mining Company (NDMC), so that taxes on profits would flow directly to his control, bypassing state revenue collectors who were siphoning the money for their own 
uses. Stevens gained control over revenues as well as control over new NDMC administrative positions that he could award to loyal allies. By 1981, at least ten of Kono's twelve chiefs had been awarded lucrative NDMC management positions.

The creation of NDMC effectively nationalised the distribution of patrimonial resources. Stevens used the authority of the Ministry of Mines to selectively issue licenses to dealers loyal to him, undercutting the loyalty of dealers to local chiefs. Dealers and chiefs quickly learned the consequences of failure to support Stevens. Using these tactics, Stevens isolated recalcitrant strongmen and imposed his control. To unseat the chief of Gbense, at the political heart of Kono, Stevens launched a commission of inquiry to investigate allegations of corruption. When Dunbar mobilized his political network around a candidate opposed to Stevens' choice, Yafenneh Toli, Stevens declared a state of emergency, then issued preventative detention decrees that were used to intimidate campaigns for the rival candidate. Once Toli was elected, he was quickly appointed to an NDMC management position, which he used to raise money to campaign for candidates supporting Stevens.

Stevens installed his allies in key positions and subcontracted the collection of revenues to them, thereby expanding the sources and amounts of revenue. Revenue was no longer limited to the formal collection of the state share of NDMC profits but now included rents paid by diamond dealers (and, thus, a portion of rents paid by illicit miners to diamond dealers). Thus, Stevens co-opted nearly every category of Sierra Leone's economically important strata - illicit miners, diamond dealers, local chiefs, and parliamentary members - to align them in support of his presidency.

Local chiefs now had powerful incentives to cooperate with governmental efforts to control illicit and legal mining so as to maximize government revenues and, thus, the resources available for distribution by Stevens. Compliant chiefs were rewarded with lucrative positions on the NDMC board, along with governmental police and paramilitary protection that could be used to extract rents from illicit and legal diamond dealers and miners. Increasingly, chiefs became dependent on revenues and protection that emanated from Stevens, rather than illicit miners and dealers. As a result, the chiefs became allies of Stevens in prosecuting uncooperative illicit miners and dealers.

The 1973 elections were rigged by Stevens and his supporters to rid the APC party of radicals who posed a threat to Stevens' rule, using the same strategies that he used to elect Toli. Stevens used his ability to control dealer licenses and prosecute out-of-favor dealers to dispense resources to favored allies, undercut and isolate recalcitrant opposition leaders, and impose discipline that few dared to challenge. In cases where these methods proved to be insufficiently persuasive, such as diamond poaching, Stevens utilized the NDMC's paramilitary Internal Security Unit (ISU), tagged 'I Shoot You' by its victims. 
Neither Stevens nor the dealers and politicians who benefited from Stevens' favor had any desire to introduce the type of free market reforms favored by the IMF and World Bank as a device for improving output and income. More competition would have diluted the monopolistic profits of favored dealers who had acquired licenses at great cost, diluting the value of the licenses and, thus, Stevens' ability to control dealers through his monopoly on the issuance of dealer licenses.

Politicians competed for Stevens' favor in order to gain access to lucrative dealer licenses, mining plots, and NDMC management positions. By 1982, twelve of Kono's fourteen chiefs held dealer licenses along with plots for diamond mining, ten chiefs held NDMC management positions, and all six of Kono's members of parliament held licenses or plots. A license enabled the average dealer to gross approximately $\$ 500,000$ in one mining season, from January to June. Importantly, dealer licenses permitted chiefs and politicians not only to make money, but to convert the money, along with rents collected through exploitation of their official positions, into purchases of diamonds. The proceeds of diamonds sold abroad for foreign currency could then be deposited in foreign bank accounts, safe from the possibility of confiscation in the event of a fall from favor.

\subsection{Erosion of Checks and Balances}

The exploitation of official positions extended to the court system. Gbense merchants complained that the paramount chief maintained 'star chamber courts,' where his relatives were appointed to adjudicate and impose fines on litigants. This revenue was split between the chief and his relatives. Thus, gross violations of the law and blatant misuse of power eroded the system of checks and balances that Western democracies rely upon to counter corrupt individuals.

The introduction of elections, rather than instilling democratic control by the populace over its elected leaders, merely served as another tool in Stevens' arsenal to discipline and control rivals as well as supporters. Stevens used his powers to control the process of nominating and electing candidates for office. To maintain a level of job insecurity for every elected official that reinforced compliance with his desires, Stevens used the same tactics that were so effective in deposing the chief of Gbense and assuring Toli's election. Selective prosecutions for corruption were orchestrated to remove recalcitrant officials and replace them with allies.

The police and security forces were corrupted as well. These highly coveted positions were awarded to Stevens supporters who took advantage of lucrative opportunities to set up roadblocks and checkpoints where identity documents were 'checked' and bribes were extracted as the price of avoiding further delay, imprisonment, or worse.

Stevens' domination of the economy was so complete that almost every citizen was subjugated to a position of obligation with regard to his network, with few 
alternatives and no easy exit. He granted attractive tax incentives to Sierra Rutile to expand rutile mining, which destroyed all plant cover, polluted water supplies, and created stagnant water ponds that bred malarial mosquitoes in the home area of one of his rivals.

At the core of Stevens' power was his monopoly on the use of force to label unsanctioned activities as 'crimes'. He used threats of prosecution and confiscation to ensure that rivals were unable to establish their own bases of power. But he also entangled international banks, the IMF and the World Bank in a web that threatened multilateral banks, ensuring that he would be treated gingerly by the international community. He financed patrimonial spending and revenue shortfalls through loans procured by his loyal network of dealers and collateralized by illicit diamond exports. These highly profitable loans, carrying high interest rates, bound private creditors tightly to Stevens in a symbiotic relationship. However, these loans were insufficient to bridge growing shortfalls, inducing the IMF and World Bank to extend increasing amounts of credit in order to avoid domino-like defaults that could damage large multilateral banks and the international banking system. A stand-by arrangement with the IMF for special drawing rights (SDR) of 17 million in 1979 quickly expanded to SDR 186 million by 1981. In return, the IMF required Sierra Leone to privatize many state-run enterprises and institute currency restrictions. However, the privatizations were rigged and steered to allies of Stevens on extremely favorable terms, while the currency restrictions were used to selectively allocate scarce currency to Stevens' supporters. Most shocking, Bank of Sierra Leone Governor Sam Bangurah was murdered after criticizing arrangements to direct $\$ 200$ million in patrimonial expenditures to Stevens' allies and refusing to authorize foreign exchange allocations directed by Stevens.

Sierra Leone failed to meet IMF-mandated reforms and conditions regarding repayment, yet received an additional SDR 20.7 million in 1983 and SDR 50.2 million in 1984 from the IMF and World Bank. Official IMF and World Bank credits provided 45 to 55 per cent of Sierra Leone's deficit financing from 1980 through 1983. This support permitted Stevens to continue using state resources for political purposes.

Stevens expanded the scope of corruption and sources of revenue by rigging IMF-mandated privatization in import-export trading, fisheries, agricultural marketing, banking, oil, construction materials, and consumer-good imports, essentially reducing the state of Sierra Leone to a gigantic personal network of corrupt associates and dependents. Stevens eventually amassed a personal fortune estimated at $\$ 500$ million. This diversion of state revenues starved and destroyed the effectiveness of most state institutions. State spending on health and education fell by 60 per cent between 1980 and 1987 . 


\subsection{Changes in Leadership}

Sierra Leone fared no better after changes in leadership. In 1986, the new president, Saidu Momoh, announced a 'New Order' of sweeping reforms aligned with IMF recommendations to attack corruption and greatly reduce governmental involvement in the economy, but applied privatization, economic liberalization and reform as weapons to discipline rivals and build his economic and political power base. In 1992, Valentine Strasser overthrew Momoh, promised reform and commitment to IMF conditions supporting divestiture, private enterprise and foreign investment, but also succumbed to corruption.

\section{Analysis}

The statements by IMF and World Bank economists in Section I suggest that they attribute anemic economic growth and poverty in Africa to dirigisme: state ownership, price controls, and the manipulation of exchange rates and foreign trade to benefit entrenched elites. IMF and World Bank economists assume that privatization, deregulation and economic competition will grow the economic power of entrepreneurs to demand efficient, ethical government leaders, thereby reversing the breakdown in law and order. The opening of African economies through currency devaluation and trade liberalization is believed to introduce pressure from international trading partners and creditors for efficient, honest governance.

Studies of Liberia, Sierra Leone, Congo, Nigeria and Cameroon suggest, on the contrary, that privatization and economic liberalization inadvertently hastens the shift of state assets into the hands of corrupt politicians and their supporters, undermining the development of central governments responsible to their citizens. ${ }^{42}$ Presidents use anticorruption tribunals to discipline associates as well as enemies. A consequence of the corruption is the erosion of education, health and social services as ruling elites cut the budget for teachers, health care workers, and other government workers who consume scarce resources but are not useful to elites seeking to strengthen their hold on power. This pattern holds throughout sub-Saharan Africa. In Congo, for example, state spending in these areas was practically cut to zero. In Zaire, President Mobutu Sese Seko cut state spending on health and education from 17.5 per cent of the state budget in 1972 to 2.1 per cent in 1990, reflecting the diversion of 95 per cent of Zaire's budget for his own use. ${ }^{43}$

\footnotetext{
42) Reno, Warlord Politics and African States, supra note 40; N. van de Walle, 'The Politics of Non-Reform in Cameroon' in T. Callaghy and J. Ravenhill (eds), Hemmed In: Responses to Africa's Economic Decline (Columbia University Press, New York 1993).

43) Reno, Warlord Politics and African States, supra note 40.
} 
Paradoxically, the World Bank's and IMF's efforts to foster good governance through privatisation and economic liberalisation provide the cover under which corrupt ruling elites dismantle and destroy individuals and institutions that could threaten their power. Donors inject funds that effectively support corrupt ruling elites. Conditioned on austerity measures, cutbacks in spending, privatisation and economic liberalisation, these funds are then manipulated by corrupt leaders to funnel resources away from enemies and towards loyal supporters. Budget cutbacks are selectively targeted to undermine political enemies. Violence is used to control commercial opportunities, the distribution of wealth, and the building of political alliances.

As Reno explains, the president becomes a warlord who rules through violence and by selectively distributing wealth. ${ }^{44}$ The president uses the power of his office to manipulate IMF-mandated privatisation, economic liberalisation and austerity measures in ways that build his wealth and political support. The president is faced with competing, regional warlords who use violence and selective distribution of wealth to rule regional bastions carved out of the sovereign territory nominally ruled by the president. Each warlord employs official and unofficial security forces funded through agreements that funnel state resources to them - access to diamonds, in the case of Sierra Leone. African leaders are ultimately compelled to reject true political liberalisation because this would merely serve to increase the independent access of opposing warlords to economic resources that would threaten the authority of the African leaders. The development of civil society, favored by the IMF as a means of building a bulwark against unfettered government power, is accurately viewed by African leaders as a potential threat to their rule. Thus, it is unrealistic to expect African ruling elites to prioritise good governance over the use of their power to instill discipline through violence and manipulation of government resources. Under these conditions, the economic liberalisation and reforms favored by the IMF and World Bank paradoxically undermine good governance.

In contrast, the rule of law in Western democracies channels economic liberalisation productively, creating wealth. It is this experience that leads IMF and World Bank economists to assume that Western-style economic and political liberalisation may be exported to African countries with the same positive effects. However, the experiences of Sierra Leone, Congo, Nigeria, Cameroon and their sub-Saharan neighbors suggest that this assumption is incorrect. A necessary prerequisite is to establish checks and balances to counter corruption and patrimonial networks.

The condition that permits patrimonial networks and embedded corruption is the uncontested capacity of ruling elites and warlords to apply unfettered control over any significant source of wealth from natural resources, foreign aid, and

44) Ibid. 
rent-extracting networks based on controlled production and prices. This lack of accountability is at the heart of Africa's poverty and slow growth. The ability of African ruling elites to militarise commerce and discipline associates and rivals through violence and intimidation allows them to perpetuate corrupt rule and counterproductive economic policies. In contrast, Western-style democracies have effectively eliminated this option, forcing politicians to operate within the law and to respond to demands from voting constituents in order to maintain power. In Africa, this mechanism is broken. Corrupt politicians selectively create, define and apply laws to reward allies and punish rivals.

Officially, African states must adopt the reforms advocated by the IMF and World Bank in order to continue receiving aid. However, implementation is manipulated so that the reforms serve the dual purpose of keeping aid flowing while maintaining discipline among associates and rivals. IMF and World Bank support for competitive elections and political liberalisation exposes African ruling elites to challenges from rivals, forcing those ruling elites to increase their reliance on patrimonial practices in order to maintain their grip on power. In an effort to control these practices, World Bank officials prescribe privatisation along with deep cuts in civil service employment in order to expose bureaucrats to market discipline and promote efficiency, modeled on reforms in Côte d'Ivoire. ${ }^{45}$ However, privatisation through alliances with foreign firms can be initiated and ended in ways that reward allies and punish rivals, without arousing the violent opposition that would occur if domestic workforces were treated in the same cavalier manner, permitting African ruling elites to continue corrupt rule and negating any need for ruling elites to become more responsive to their voting constituents in order to maintain power. Commercial alliances allow ruling elites to dominate wealth created from state-owned resources and pay for security services contracted out to foreign firms, allowing ruling elites to jettison unreliable military officers who might otherwise seize power through a coup d'état. In sum, African ruling elites are not accountable to their citizens, breeding opposing warlords who contest the power of those elites through violence, which triggers even more repressive, dictatorial, self-aggrandizing behavior from those in power.

In view of the evidence reviewed in Sections II and III, the assertions by IMF and World Bank economists in Section I that privatisation, deregulation, economic liberalisation and restructuring will limit the scope for corruption are naive. Instead of limiting corruption, these policies are manipulated by corrupt African leaders to shift state assets into the hands of their allies, enhance their revenue streams, and punish their rivals. This occurs because of the lack of effective checks and balances on their power. This lack of accountability cannot be fixed by requiring transparency, promoting competitive elections, bolstering the

45) Ibid. 
judiciary, passing laws against corruption, or establishing domestic anticorruption agencies. All of these strategies have been tried, and all have failed. The reason is that they have been manipulated by corrupt leaders to reward allies and punish rivals. Reforms that are limited to domestic laws, regulations, agencies and personnel are susceptible to the corruption that pervades African governments.

This analysis suggests a conclusion that has largely been overlooked by development specialists: the international community must create and implement a powerful international check against corruption in Africa. Up to this point, development theorists, planners and economists have focused their guidance primarily on changes in domestic laws, regulations, policies, agencies, institutions, and leaders. ${ }^{46}$ Privatisation, deregulation, economic liberalisation, and restructuring are examples of changes that are necessarily implemented through changes in domestic laws, regulations, policies, agencies and institutions and, therefore, are easily manipulated by corrupt African elites.

Furthermore, an effective intervention against corruption must be powerful. No Western developed country relies on privatisation, deregulation, and economic competition to deter corruption. These are weak forces against corruption. Instead, corruption is held in check through aggressive investigation and prosecution. In African countries, however, corrupt leaders manipulate the domestic police, anticorruption agencies, judiciary, legal system, laws, regulations, and policies to their own advantage. This suggests that the problem of corruption in Africa cannot be addressed through domestic reforms that are easily manipulated by corrupt elites. Instead, the international community must create and implement a system where international inspectors who are largely immune from pressure exerted by powerful African elites are empowered to respond to requests by African citizens to conduct impartial investigations.

This suggestion immediately raises a host of issues. What is the legal basis for a system of international inspections? Why would African leaders, especially corrupt leaders, agree to international inspections? How would this work in practice? How would it be funded? How would international inspections fit with existing domestic laws and procedures for prosecuting corruption? How could international inspectors operate with sufficient freedom to be effective, while respecting domestic laws? While there is insufficient space to answer these questions here, I have drafted a protocol that would supplement the United Nations Convention Against Corruption (UNCAC), draw upon the legal authority established

46) But see P. Collier, The Bottom Billion: Why the Poorest Countries Are Failing and What Can Be Done About It (Oxford University Press, Oxford 2007). Collier advocates international charters that would create codes of conduct, increase transparency with regard to the revenues from natural resource extraction, promote free elections and a free mass media, promote transparency in budgeting, outlaw government expropriation of private assets, and require international banks to report the deposit of large sums of money. However, none of these tactics would create a powerful, independent check against corruption, free from manipulation by corrupt leaders. 
by UNCAC to establish an African Commission Against Corruption (ACAC) modeled after Hong Kong's highly successful Independent Commission Against Corruption (ICAC), and employ United Nations inspectors to respond to requests by African citizens to investigate alleged corruption at every level, and across every branch, of government (see http://www.box.net/shared/ua9y4dev9a). Details about how and why this could work are available online (see http://www .box.net/shared/l1d31586h8).

The draft protocol would effectively provide an independent means of investigating corruption, and would apply to any African state that signed and ratified the protocol. Under the protocol, any individual could submit a request for an investigation. The UN Commission on Crime Prevention and Criminal Justice, through the ACAC, would assess the validity of each charge and would provide a check against politically-motivated investigations. Importantly, the ACAC would have the authority to investigate counterclaims that a given investigation is politically-motivated. The ACAC would serve as an independent arbiter of conflicting charges of corruption. The ACAC would have the authority to conduct multiple investigations simultaneously to sort out conflicting claims, and would have the authority to recommend charges against multiple parties.

Trials would be conducted by domestic courts, unless crimes were to be referred to the International Criminal Court. Thus, the ACAC would have no power to convict, sentence and imprison suspects (other than the temporary detention of suspects before they are handed over for trial). This separation of powers has been effective in Hong Kong in ensuring that the powers of investigation are not abused. At the same time, the lack of power to convict and sentence suspects is a potential weakness that could be exploited by corrupt African leaders. However, any interference with prosecutions and the courts would itself be a major crime subject to investigation as an act of corruption. Repeated instances would be brought to the attention of the international community through ACAC reports filed with Transparency International, and this could be expected to adversely affect Transparency International and African Peer Review ratings, triggering financial sanctions by donors, the World Bank, and the IMF, flight of foreign investment, adverse publicity through the media, and erosion of electoral support that could unseat corrupt incumbents.

While it may seem unlikely that merely investigating corruption can stop it, this is exactly what happened in Hong Kong. The Hong Kong ICAC did not have the power to convict, sentence or imprison suspects, yet was very successful in halting corruption. The presence of independent investigators has a powerful effect on corrupt officials across all branches of government. When officials know that their telephones may be tapped, that any meeting might be recorded, and that any colleague may provide evidence to prosecutors, the scope for corruption is drastically reduced. However, this is only the case when there is a truly 
independent body of inspectors that is perceived as incorruptible. This is what is needed, but has yet to be established by the international community. ${ }^{47}$

It is evident that senior IMF and World Bank economists assume that privatisation, deregulation, economic liberalisation and restructuring will limit the scope for corruption. The evidence reviewed here suggests that this assumption is incorrect. The concentration of economic and political power in the heads of African states, as a consequence of colonial policies, effectively removed checks and balances against that power. Concentrated power is routinely used by African leaders and their loyal supporters to subvert purely domestic reforms - including privatisation, deregulation, economic liberalisation and restructuring - to amass personal wealth and punish rivals. These conclusions are not controversial. Numerous development specialists have made these points before. ${ }^{48}$

What has been overlooked, however, is that the monopolization of domestic power by African heads of state for corrupt purposes implies that an effective intervention against corruption can only come from outside the state. The only plausible candidate is the UN, which is the only international institution with sufficient moral authority and resources. Previous development specialists, almost without exception, have advocated reforms that rely on changes in domestic laws, regulations, policies, and agencies, but these domestic reforms are routinely subverted by powerful African elites.

Most importantly, an effective intervention against corruption necessarily involves the vigorous investigation and prosecution of corruption. The primary examples of successful interventions against grand corruption are the establishment

\footnotetext{
47) Another issue is how peace and security could be restored in failed states so that international inspections could proceed. However, the success of UN forces, ECOMOG (a multinational military force backed by the 16-nation Economic Community of West African States), and forces trained by Executive Outcomes in restoring peace and security in Sierra Leone suggests that a well-trained multinational force can be effective in restoring peace and security. This security helped to attract foreign investors, permit mining operations to resume, expand employment of individuals formerly employed as rebel soldiers, increase state revenues, revitalize the Sierra Leone government, defeat the Revolutionary Unity Front and permit free elections (see W. Reno, Warlord Politics and African States, supra note 40). After completing the disarmament process, UN peacekeeping forces withdrew, Ernest Bai Koroma was elected president, and an international criminal court convicted three leaders of the RUF for crimes against humanity and sentenced them to prison for terms ranging from 25 to 52 years. With funding by the international community, ECOMOG could be expanded, trained and deployed as a pan-African military force, under the auspices of the African Union and with the backing of African states that would be expected to contribute troops.

48) See Ayittey, supra note 4; Mbaku, 'Bureaucratic and Political Corruption in Africa,' supra note 4; Mbaku, 'Corruption and the Crisis of Institutional Reforms in Africa,' supra note 4; Mbaku, 'Bureaucratic Corruption in Africa: The Futility of Cleanups,' supra note 4; Mamdani, supra note 14; Reno, supra note 34; Reno, supra note 40; M. Szeftel, 'Misunderstanding African Politics: Corruption and the Governance Agenda' (1998) 25 Review of African Political Economy; M Szeftel, 'Between Governance and under-Development: Accumulation and Africa's "Catastrophic Corruption"' (2000) 27 Review of African Political Economy; M. Szeftel, 'Clientelism, Corruption and Catastrophe' (2000) 27 Review of African Political Economy.
} 
of the ICAC in Hong Kong and the Corrupt Practices Investigation Bureau (CPIB) in Singapore. ${ }^{49}$ In these states, corruption was only effectively addressed after the establishment of truly independent bodies of inspectors.

If investigations must be conducted in order to deter future corruption, if those investigations must be conducted by independent investigators who are immune to pressure from powerful African elites, and if the UN is the only international institution with sufficient moral authority and resources, only UN inspectors could conceivably fulfill this requirement. The conclusion of the present analysis is that the need for an independent body of inspectors to vigorously investigate corruption in Africa implies that the UN must field a large force of inspectors who are viewed as incorruptible and who are available to respond to requests by African citizens to investigate allegations of corruption.

This conclusion contrasts sharply with the conclusions of prominent development specialists. ${ }^{50}$ However, if the analysis presented here is correct, there is an alternative way of thinking about the problem of corruption and underdevelopment in Africa that merits consideration.

\footnotetext{
49) See M. Manion, Corruption by Design: Building Clean Government in Mainland China and Hong Kong (Harvard University Press, Cambridge, MA 2004); B.E.D. de Speville, 'The Experience of Hong Kong, China, in Combating Corruption' in R. Stapenhurst and S.J. Kpundeh (eds), Curbing Corruption: Toward a Model for Building National Integrity (The World Bank, Washington, D.C. 1999); TA Leak, 'The Experience of Singapore in Combating Corruption' in R. Stapenhurst and S.J. Kpundeh (eds), Curbing Corruption: Toward a Model for Building National Integrity (The World Bank, Washington, D.C. 1999).

50) See Collier, supra note 46; W. Easterly, The White Man's Burden: Why the West's Efforts to Aid the Rest Have Done So Much Ill and So Little Good (Penguin Press, London 2006); D. Rodrik, One Economics, Many Recipes: Globalization, Institutions, and Economic Growth (Princeton University Press, Princeton, NJ 2007); J. Sachs, The End of Poverty: Economic Possibilities for Our Time (Penguin, New York, NY 2006).
} 